\title{
Kraepelin's description of chronic mania: a clinical picture that meets the behavioral variant frontotemporal dementia phenotype
}

\author{
A descrição de Kraepelin de mania crônica: um quadro clínico que corresponde ao \\ fenótipo da variante comportamental da demência fronto-temporal \\ Leandro Boson Gambogi, ${ }^{1,2}$, Henrique Cerqueira Guimarães ${ }^{1,2}$, Mauricio Viotti Daker $^{3}$, Leonardo Cruz de Souza ${ }^{1,2}$, \\ Paulo Caramelli1,2
}

\begin{abstract}
Chronic mania is an under-investigated condition and few reports have associated this disorder with an organic background. The present work examines Kraepelin's reliable description of chronic mania from a current behavioral neurology viewpoint. Kraepelin had described a cluster of symptoms that are now recognized as core manifestations of the behavioral variant frontotemporal dementia (bvFTD) clinical phenotype. We also carried out additional reviews of original manuscripts from Kraepelin's peers, in order to find any case reports that might fulfill the current diagnostic proposal for bvFTD. Even though we failed to find an ideal case, we found some scholars who seemed to agree that chronic mania should be considered a special form of dementia. The present work highlights, through historical data, the possible overlapping features between primary psychiatric disorders and neuropsychiatric symptoms secondary to neurodegenerative conditions.
\end{abstract}

Keywords: bipolar disorder; frontotemporal dementia; geriatric psychiatry; phenotype.

\section{RESUMO}

A mania crônica constitui uma condição subinvestigada e alguns trabalhos têm associado esta desordem a um substrato orgânico. O presente manuscrito analisa a descrição fidedigna de Kraepelin de mania crônica a partir de um ponto de vista atual da neurologia comportamental. Concebemos que ele havia descrito um conjunto de sintomas que atualmente é reconhecido como manifestações centrais do fenótipo clínico da variante comportamental da demência frontotemporal (bvFTD). Também realizamos uma revisão adicional de manuscritos originais de pares contemporâneos de Kraepelin, a fim de procurar por um único relato de caso que poderia preencher critério diagnóstico atual de bvFTD. Mesmo que não tenhamos conseguido encontrar um caso perfeitamente exemplar, identificamos que alguns estudiosos da época pareciam concordar que a mania crônica devesse ser considerada uma forma especial de demência. 0 presente trabalho destaca por meio de dados históricos a sobreposição entre transtornos psiquiátricos primários e sintomas neuropsiquiátricos secundários a doenças neurodegenerativas.

Palavras-chave: transtorno bipolar; demência frontotemporal; psiquiatria geriátrica; fenótipo.

The term "mania" was used to denote madness for a long period of time. However, it was only in the first half of the nineteenth century that scholars started to advocate that mania should be regarded as an affective disorder ${ }^{1}$.

In 1899, Emil Kraepelin, a highly prominent German psychiatrist, outlined in the chapter "Manic-depressive Illness", from the $6^{\text {th }}$ edition of his treatise, a concept of a mental disease that encompassed a variety of clinical pictures, such as the periodic and circular insanity, simple melancholia and mania. He stated that, contrary to what was observed with dementia praecox, after a mood disorder episode the symptoms could totally remit. Nevertheless, patients with severe and multiple attacks of manic-depressive illness, or during aging, might have lower odds of full recovery and end up with chronic symptoms ${ }^{2}$.

Chronic mania has long been observed and described by many clinicians, such as Pinel (1802), Esquirol (1838),

'Universidade Federal de Minas Gerais, Faculdade de Medicina, Departamento de Clínica Médica, Grupo de Pesquisa em Neurologia Cognitiva e do Comportamento, Belo Horizonte MG, Brasil;

¿Universidade Federal de Minas Gerais, Programa de Pós-Graduação em Neurociências, Belo Horizonte MG, Brasil;

${ }^{3}$ Universidade Federal de Minas Gerais, Faculdade de Medicina, Departamento de Saúde Mental, Belo Horizonte MG, Brasil.

Correspondence: Paulo Caramelli; Departamento de Clínica Médica, Faculdade de Medicina da UFMG; Avenida Alfredo Balena, 190 / Sala 246; $30130-100$ Belo Horizonte MG, Brasil; E-mail: caramelli@ufmg.br

Conflict of interest: There is no conflict of interest to declare.

Received 12 November 2015; Received in final form 23 March 2016; Accepted 18 May 2016. 
Griesinger (1865), Schott (1904), Kraepelin (1913) and Wertham (1929). Many authors of that time described the evolution of chronic mania into moria, within a generally-accepted idea that affective states could evolve into a secondary chronic mental weakness and into dementia ${ }^{3}$.

Schott, who was cited by Kraepelin in his $8^{\text {th }}$ edition ${ }^{4}$, reviewed chronic mania, described four cases, and concluded that the clinical picture was similar to a mild presentation of acute mania, with minor loss of attention, memory, knowledge and mental activity, but with marked ethical loss, poor judgment and insight ${ }^{5}$. Acknowledging those protracted impairments, Schott considered chronic mania as a "special form of dementia" and emphasized the extreme heritability in most cases.

In 1978, Krauthammer and Klerman expanded the concept of mania and proposed the nomenclature "secondary mania" to those cases supposedly associated with organic dysfunction, either medical or pharmacological, particularly in patients without a history of affective disorder ${ }^{6}$. In this context, the behavioral variant of frontotemporal dementia (bvFTD) has repeatedly been reported as a possible cause of manic presentations ${ }^{7}$. Indeed, diagnostic criteria for FTD were first proposed in 1994, and updated in 1998, and from the outset, both sets of criteria highlighted symptoms commonly observed in bipolar patients during a manic episode.

Recently, diagnostic criteria for bvFTD have been revised, bringing substantial gains in sensitivity. Accordingly, core behavioral features include: 1) social disinhibition, 2) loss of sympathy or empathy, 3) apathy, 4) hyperorality and dietary changes, 5) perseverative, stereotyped or compulsive behavior, and 6) a neuropsychological profile characterized by executive dysfunction. According to current recommendations, a bvFTD phenotype can be confirmed if progressive deterioration of behavior and/or cognition is established, along with the presence of at least three of the six main clinical symptoms ${ }^{8}$.

In the following paragraphs we dissect Kraepelin's authoritative description of chronic mania ${ }^{9}$, correlating current criteria for bvFTD with his report.

Patients with bvFTD typically manifest behavioral disinhibition, with socially inappropriate conduct, including loss of manners, careless actions and even legal infractions. Kraepelin stated: "They like to interfere in everything, act as guardians to the feebler patients, snarl at them, take from them what they want." (...) "They can meantime scarcely, or not at all, be employed for profitable work on account of their unsteadiness and indifference as well as their inclination to all sorts of mischief.(... "... talk more than their share, swagger, try to gain for themselves all possible little advantage."

The lack of empathy, loss of sympathy and social isolation are a hallmark of bvFTD. Those symptoms were described by Kraepelin as: "The finer emotions are considerably injured. The patients show little interest in their relatives, do not shrink from making coarse jokes about them,..."
Apathy is frequently observed in bvFTD and may be the main behavioral manifestation of the disorder. These symptoms are also highlighted in Kraepelin's description of chronic mania: “...do not trouble themselves about their affairs, do not worry at all about their position and their future, at most once in a day they beg without energy for discharge."(...)...everything else has become to them more or less indifferent."

The presence of dietary changes and hyperorality are also included as a diagnostic behavioral symptom of bvFTD. Patients may have increased cigarette or alcohol consumption, and gluttonous overeating. Interestingly, Kraepelin also hints about these changes: "Only the coarser enjoyments, eating, drinking, smoking, snuffing, still arouse in them vivid feelings, further the satisfaction of their personal wishes and wants."

Compulsive and ritualistic behaviors, including collectionism and hoarding, are observed in patients with bvFTD. Patients are typically prone to pick up objects in the surroundings and store them, collecting useless, old or damaged items. Again, as Kraepelin: "They collect all possible rubbish in their pockets, make a mess with it all round about, rub and wipe things, adorn themselves with rags and scraps of ribbon,..."(Figure).

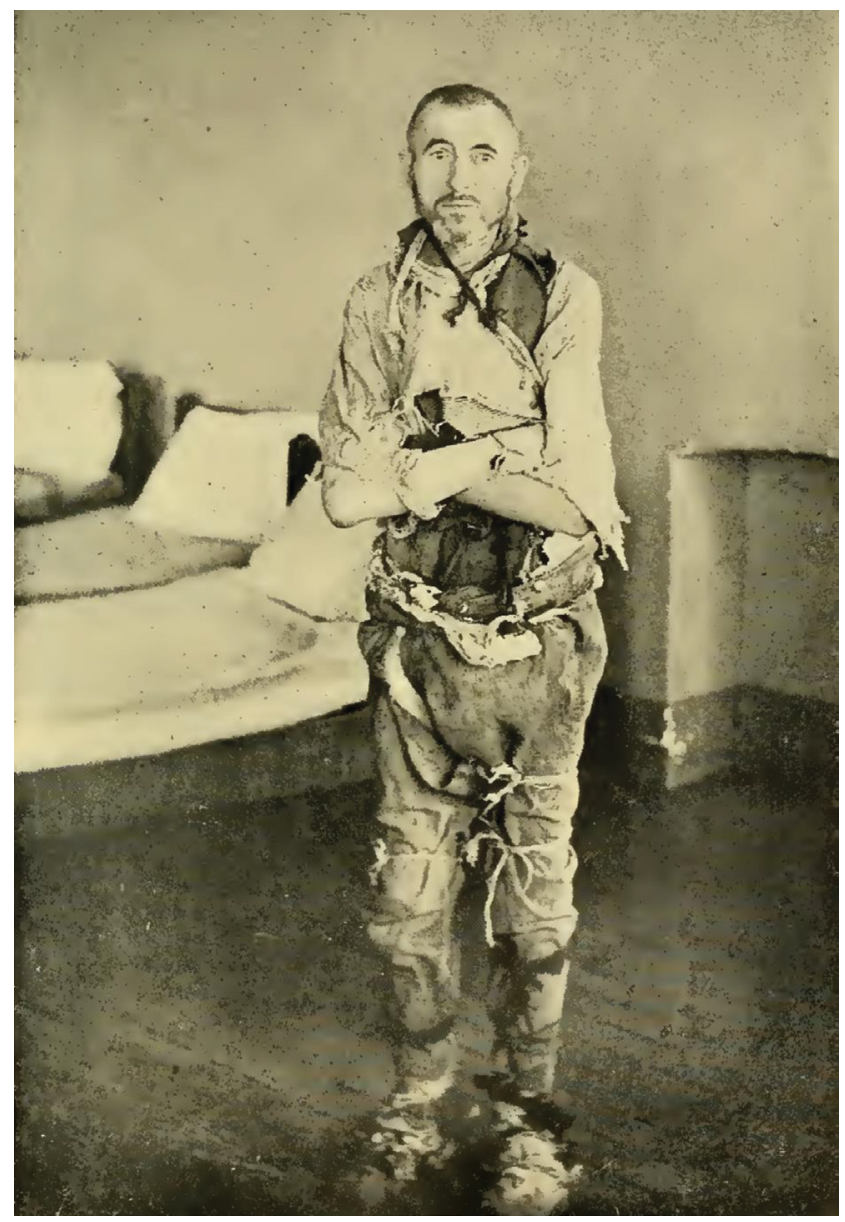

(Kraepelin 1904/translated in 1912, p. 397)

Figure. Self-decorated manic patient. 
In summary, the description of chronic mania provided by Kraepelin in 1913 depicts a cluster of symptoms that closely resembles the bvFTD phenotype. We should keep in mind that Kraepelin was especially concerned with the description and classification of mental diseases based upon symptoms, course and outcome, since he considered etiologic and neuroanatomical findings a step ahead of the clinical identification of diseases ${ }^{10,11}$. We must also recognize, that after the last twenty years of accumulated research on FTD, we stand on more solid footing, which was unavailable to Kraepelin or to past clinicians. Accordingly, we did not expected to find the neuropathologic descriptions that we know today in his texts. Indeed, in his reports on the "physical causes" of manic-depressive illness, we found nothing but a review of several unspecific affections ${ }^{9}$. Nevertheless, we may conceive that some chronic mania patients of that time, as described by Kraepelin, could have fit within current diagnostic criteria for possible bvFTD.

Though being aware of the limitations imposed by the restricted bibliography consulted, the present work may be read as an historical illustration of the complex relationships between primary severe psychiatric disorders and neuropsychiatric symptoms secondary to neurodegenerative conditions. Recently, neuroimaging and genetic studies have demonstrated that there may be a common neurobiological foundation between those conditions, at least in a small subset of patients ${ }^{12}$. It is known that selected mutation carriers display a slowly progressive disease course, sometimes with a long lasting psychiatric prodrome. Further research may elucidate to what extent the clinical descriptions of bvFTD and chronic mania refer to distinct clinical entities or to a spectrum with common pathophysiological processes.

\section{References}

1. Bucknill JC, Tuke DH.A Manual of psychological medicine, containing the history, nosology, description, statistics, diagnosis, pathology, and treatment of insanity. London: John Churchill; 1858.

2. Kraepelin E. Ein Lehrbuchfür Studierende und Ärzte. 6th ed. Leipzig: Johann Ambrosius Barth; 1899.

3. Griesinger W. Pathologie und Therapie der psychischen Krankheiten. Berlin: Braunschweig; 1861.

4. Kraepelin E. Ein Lehrbuchfür Studierende und Ärzte. 8th ed. Leipzig: Johann Ambrosius Barth; 1913.

5. Schott A. Klinischer Beitragzur Lehre von der chronischen Manie. Monatschr Psychiat Neurol. 1904;15:1-19.

6. Krauthammer C, Klerman GL. Secondary mania: manic syndromes associated with antecedent physical illness or drugs. Archs Gen Psychiatry. 1978;35(11):1333-9.

7. Woolley JD, Wilson MR, Hung E, Gorno-tempini ML, Miller BL, Shim J. Frontotemporal dementia and mania. Am J Psychiatry. 2007;164(12):1811-6.
8. Rascovsky K, Hodges JR, Knopman D, Mendez MF, Kramer JH, Neuhaus $J$ et al. Sensitivity of revised diagnostic criteria for the behavioural variant of frontotemporal dementia. Brain. 2011;134(9):2456-77. doi:10.1093/brain/awr179

9. Kraepelin E. Lehrbuch der Psychiatrie. In: Robertson G, ed. Manic-depressive insanity and paranoia. 8th ed. Edinburg: E. \& S. Livingstone; 1913. p. 161-2.

10. Angst J. Historical aspects of the dichotomy between manic-depressive disorders and schizophrenia. Schizophrenia Res. 2002;57:5-13. doi:10.1016/S0920-9964(02)00328-6

11. Mondimore FM. Kraepelin and manic-depressive insanity: an historical perspective. Int Rev Psychiatry. 2005;17(1):49-52. doi:10.1080/09540260500080534

12. Meisler MH, Grant AE, Jones JM, Lenk GM, He F, Todd PK et al. C9ORF72 expansion in a family with bipolar disorder. Bipolar disorders. 2013;15(3):326-32. doi:10.1111/bdi.12063 